\title{
PEMBENTUKAN TAMAN HIJAU DENGAN MENGGUNAKAN SAMPAH PLASTIK
}

\author{
Alpiana1), Diah Rahmawati ${ }^{1)}$, Joni Safaat Adiansyah ${ }^{11}$ \\ 1)Program Studi Teknik Pertambangan, Fakultas Teknik, Universitas Muhammadiyah Mataram, Mataram, Indonesia \\ Corresponding author : Alpiana \\ E-mail : alpiana0901@gmail.com
}

Diterima 6 Maret 2018, Disetujui 5 April 2018

\begin{abstract}
ABSTRAK
Sampah merupakan salah satu permasalahan yang ada di sekitar kita, dimana sumber sampah salah satunya berasal dari suatu kelompok dengan jumlah aktivitas manusia yang komposisinya $75 \%$ terdiri dari sampah organik dan $25 \%$ sampah anorganik. Sampah anorganik yang paling banyak dijumpai di masyarakat adalah sampah plastik. Pada tahun 2008 produksi sampah plastik untuk kemasan mencapai 925.000 ton dan sekitar $80 \%$ berpotensi menjadi sampah yang berbahaya bagi lingkungan. Karena potensi yang cukup besar, alangkah lebih baik untuk dimanfaatkan sampah plastik ini menjadi suatu produk yang mendukung kehidupan kita. Salah satu cara pemanfaatan sampah plastik khususnya yang berasal dari sampah botol minimum yaitu dengan penggunaan sampah botol menjadi pot untuk taman hijau akan membantu Universitas Muhammadiyah Mataram memiliki gerakan menanam dan mengurangi sampah plastik. Kegiatan pengabdian pada masyarakat menggunakan sampah plastik untuk dibuatkan menjadi pot yang dapat digantung atau dirangkai sehingga bisa menjadi taman hijau. Bahan-bahan yang digunakan yaitu sampah plastik dan kawat atau tali. Bahan-bahan yang digunakan dilakukan pengumpulan terlebih dahulu, dilakukan pemilahan, membersihkan plastik, membentuk pot, melakukan penanaman, dan dilakukan perawatan. Mitra dalam kegiatan pengabdian pada masyarakat adalah pengelola kantin dan mahasiswa. Kegiatan pengabdian pada masyarakat melibatkan mitra pengelola kantin yang berperan untuk pengumpulan botol plastik yang nantinya akan dipilih sesuai dengan kebutuhan pot yang dibuat untuk taman hijau dan mahasiswa yang berperan menjadi pionir dalam membuat taman hijau dan perawatan untuk taman hijau. Taman hijau yang telah terbentuk telah menjadi langkah kecil untuk mencapai zero waste yang merupakan program NTB Gemilang.
\end{abstract}

Kata kunci : sampah; plastik; taman hijau.

\begin{abstract}
Garbage is one of the problems around us, where one source of waste comes from a group with a total of $75 \%$ of human activity consisting of organic waste and $25 \%$ inorganic waste. Inorganic waste that is most often found in the community is plastic waste. In 2008 the production of plastic waste for packaging reached 925,000 tons and around $80 \%$ has the potential to become hazardous waste for the environment. Because of its considerable potential, it would be better to make use of this plastic waste into a product that supports our lives. One way to utilize plastic waste, especially those originating from minimum bottle waste, is the use of bottle waste into pots for green parks will help the University of Muhammadiyah Mataram have a movement to plant and reduce plastic waste. Community service activities use plastic waste to be made into pots that can be hung or strung together so that they can become green parks. The materials used are plastic waste and wire or rope. The materials used are collected in advance, sorting, cleaning plastics, forming pots, planting, and carried out maintenance. Partners in community service activities are canteen managers and students. Community service activities involve canteen management partners whose role is to collect plastic bottles which will be selected according to the needs of pots made for green parks and students who play a pioneering role in making green parks and care for green parks. The green park that has been formed has become a small step towards achieving zero waste which is the NTB Gemilang program.
\end{abstract}

Keywords : garbage; plastic; green garden.

\section{PENDAHULUAN}

Menurut Putra H.P dan Yuriandala Y. Tahun 2010, Sumber sampah salah satunya berasal dari suatu kelompok dengan jumlah aktivitas manusia yang banyak, dengan komposisinya berupa $75 \%$ terdiri dari sampah organik dan $25 \%$ sampah anorganik. Sampah organik telah banyak dimanfaatkan sebagai bahan pembuatan kompos, briket serta biogas, tetapi sampah anorganik masih sangat minim 
pengelolaanya. Sampah anorganik sangat sulit di degradasi bahkan tidak dapat didegradasi sama sekali oleh alam. Oleh karena itu diperlukan lahan yang sangat luas untuk mengimbangi produksi sampah jenis ini. Sampah anorganik yang paling banyak dijumpai di masyarakat adalah sampah plastik. Pada tahun 2008 produksi sampah plastik untuk kemasan mencapai 925.000 ton dan sekitar $80 \%$ berpotensi menjadi sampah yang berbahaya bagi lingkungan. Karena potensinya yang cukup besar, alangkah lebih baik untuk dimanfaatkan sampah plastik ini menjadi suatu produk yang mendukung kehidupan kita.

Menurut Sahwan F.L dkk pada tahun 2005, plastik merupakan bahan yang paling banyak digunakan. Penggunaan bahan plastik semakin lama semakin meluas dan meningkat. Perkembangan produk plastik di Indonesia sangat pesat pada dua dekade terakhir dengan merambah hampir disemua jenis kebutuhan manusia.

Salah satu cara pemanfaatan sampah plastik khususnya yang berasal dari sampah botol minuman yaitu dengan penggunaan sampah botol menjadi pot untuk konsep taman hijau di Kampus Universitas Muhammadiyah Mataram. Konsep taman hijau akan akan membantu Kampus Universitas Muhammadiyah Mataram memiliki gerakan menanam dan mengurangi sampah plastik. Tentunya langkah ini merupakan langkah kecil untuk mewujudkan Zero Waste yang menjadi slogan yang didengungkan oleh Gubernur dan Wakil Gubernur Provinsi Nusa Tenggara Barat. Upaya ini juga akan melatih mahasiswa dan civitas akademika untuk menjaga lingkungan.

\section{METODE}

Dalam kegiatan pengabdian pada masyarakat yang akan dilakukan yaitu dengan menggunakan sampah botol plastik untuk dibuatkan menjadi pot yang dapat digantung atau dirangkai sehingga bisa menjadi taman hijau. Adapun bahan-bahan yang dibutuhkan dalam pembuatan taman hijau ini yaitu :

1. Sampah botol plastik

2. Kawat/tali

Adapun langkah-langkah yang akan dilakukan dalam pembuatan taman hijau dengan menggunakan sampah botol plastik yaitu :
1. Melakukan pengumpulan sampah botol plastik yang ada di kawasan Kampus Universitas Muhammadiyah Mataram.

2. Sampah botol plastik yang telah dikumpulkan akan dibersihkan.

3. Melakukan pembuatan pot dengan memotong beberapa bagian dari plastik botol untuk menanam tanaman.

4. Melakukan rangkaian botol-botol plastik dengan bentuk hexagonal dengan menggunakan kawat.

5. Memasukkan media tanam di botol-botol yang telah dirangkai.

6. Menanam tanaman

Kegiatan pembuatan taman hijau ini akan dipusatkan terlebih dahulu di Fakultas Teknik, dimana kegiatannya tidak hanya terhenti pada saat tanaman sudah ditanam, melainkan akan berlanjut dengan menggerakkan mahasiswa sebagai pelaku penjaga lingkungan. Bagaimana peran penjaga lingkungan ini? Mereka akan bergiliran melakukan penyiraman dan merawat tanaman yang ada di taman hijau. Dengan peran yang dilakukan secara bersama maka akan membuat taman hijau bukan hanya sebuah bentuk pengabdian pada masyarakat tetapi bentuk kepedulian kita semua terhadap lingkungan terutama untuk pengurangan sampah.

Dalam kegiatan pengabdian kepada masyarakat ini melibatkan beberapa unsure atau mitra yaitu:

1. Pemilik Kantin

2. Mahasiswa

\section{HASIL DAN PEMBAHASAN}

a) Mitra dalam kegiatan

Dalam kegiatan pengabdian pada masyarakat mitra yang terlibat adalah :

$>$ Pemilik Kantin ; memiliki peran untuk mengumpulkan botol plastik yang nantinya akan dipilah sesuai dengan kebutuhan pot yang akan dibuat untuk taman hijau. Jadi, sampah botol plastik akan dikumpulkan dan tidak berserakan ataupun dibuang ke suangai. Hal ini tentu menjadi kesadaran bahwa membuang sampah terutama botol plastic di sungai adalah hal yang kurang baik.

> Mahasiswa/Himpunan Mahasiswa Teknik Pertambangan ; berperan menjadi pionir pelaksana dalam kegiatan ini. Mahasiswa dilatih untuk mengambil sampah botol 
plastic untuk dibersihkan kemudian dilakukan pemotongan botol plastic sesuai dengan kebutuhan. Mahasiswa juga berperan dalam menanam tanaman ataupun bunga kemudian melakukan perawatan.

b) Pelaksanaan Kegiatan Pengabdian pada masyarakat

Kegiatan pembuatan taman hijau ini akan dipusatkan terlebih dahulu di Fakultas Teknik, dimana kegiatannya tidak hanya terhenti pada saat tanaman sudah ditanam, melainkan akan berlanjut dengan menggerakkan mahasiswa sebagai pelaku penjaga lingkungan. Bagaimana peran penjaga lingkungan ini? Mereka akan bergiliran melakukan penyiraman dan merawat tanaman yang ada di taman hijau. Dengan peran yang dilakukan secara bersama maka akan membuat taman hijau bukan hanya sebuah bentuk pengabdian pada masyarakat tetapi bentuk kepedulian kita semua terhadap lingkungan terutama untuk pengurangan sampah. Langkahlangkah kegiatan yang dilakukan yaitu :

1. Melakukan pengumpulan sampah botol plastik yang ada di kawasan Kampus Universitas Muhammadiyah Mataram, kegiatan pengumpulan sampah dilakukan oleh pemilik kantin (Gambar 1)

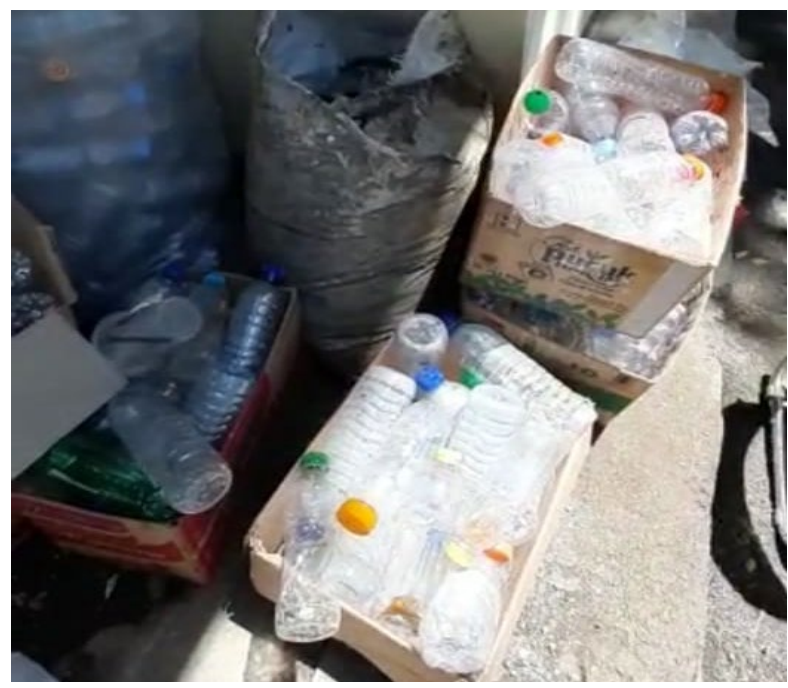

Gambar 1. Kegiatan pengumpulan botol plastik untuk pembuatan taman hijau

2. Sampah botol plastik yang telah dikumpulkan akan dibersihkan, dan kegiatan pembersihan ini dilakukan oleh mahasiswa.
3. Melakukan pembuatan pot dengan memotong beberapa bagian dari plastik botol untuk menanam tanaman (Gambar 2) dimana kegiatan pembuatan pot ini dilakukan oleh mahasiswa dengan memotong bagian botol plastik.

4. Melakukan rangkaian botol-botol plastik dengan bentuk hexagonal dengan menggunakan kawat.

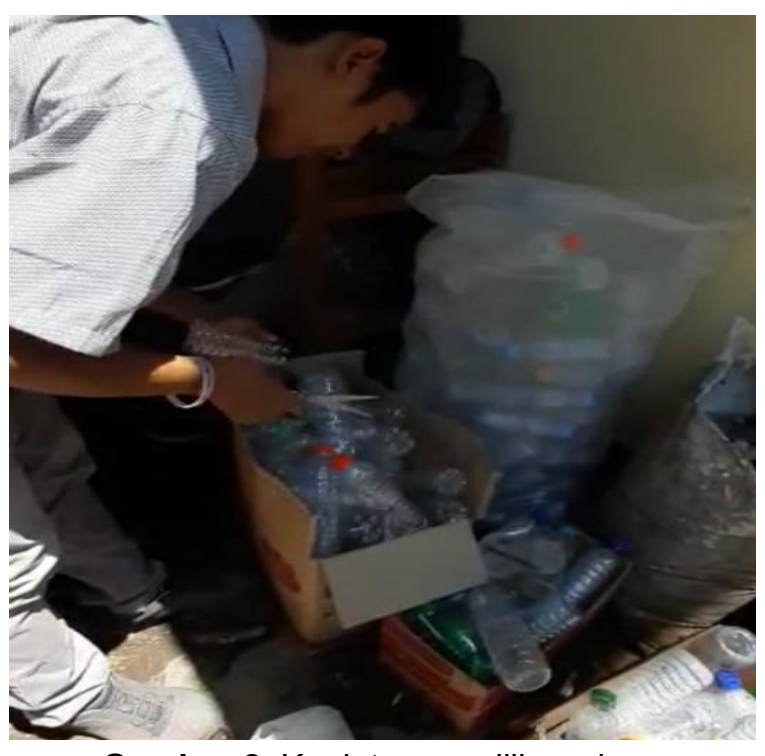

Gambar 2. Kegiatan pemilihan dan pembersihan botol plastik

5. Memasukkan media tanam di botol-botol yang telah dirangkai (Gambar 3)

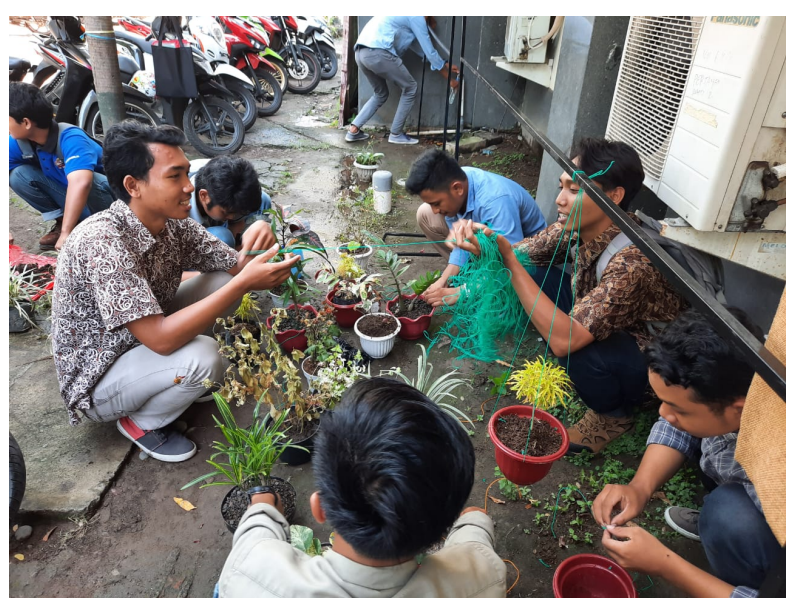

Gambar 3. Kegiatan perangkaian botol plastik untuk taman hijau

6. Melakukan perangkaian pot taman hijau dalam rangka yang telah dibuat (Gambar 4). Rangkaian ini sekaligus dilakukan pengecatan terhadap pot bunganya yang telah ditanam sebelumnya. 


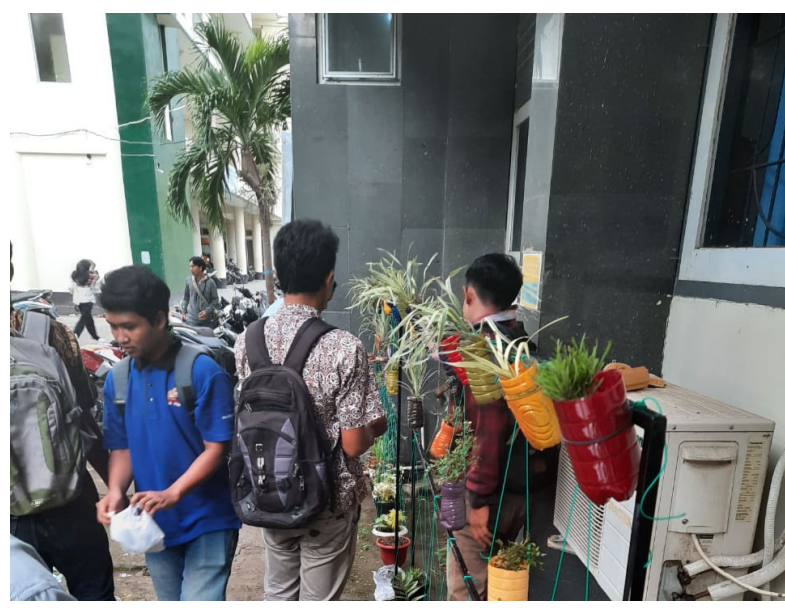

Gambar 4. Kegiatan perangkaian taman hijau

Setelah dilakukan perangkaian pembentukan taman hijau akan dilakukan pengecatan. Hasil pembentukan taman hijau dapat dilihat pada gambar 5 .

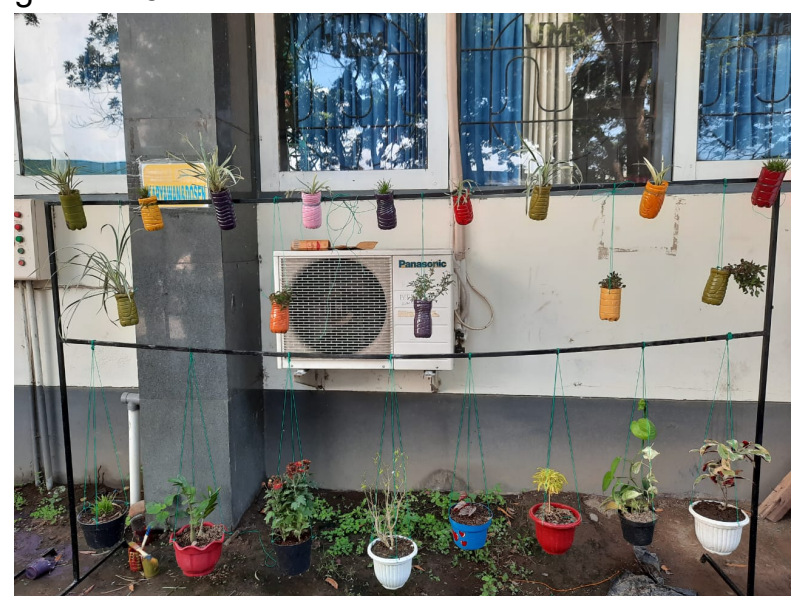

Gambar 5. Hasil Taman Hijau Fakultas Teknik

\section{KESIMPULAN DAN SARAN}

\section{Simpulan}

Kesimpulan dalam kegiatan pengabdian pada masyarakat ini yaitu pembuatan tamana hijau sukses dilakukan, dengan menggunakan peran dari beberapa pihak yaitu penjaga kantin, Dosen, dan Mahasiswa.

\section{Saran}

Saran dalam kegiatan pengabdian kepada masyarakat yaitu :

1. Perlu peran bersama dari semua civitas akademika untuk mensukseskan kegiatan pengabdian pada masyarakat

2. Perlu masterplan penataan sungai di sekitar kampus Universitas Muhammadiyah Mataram

\section{DAFTAR RUJUKAN}

Hermono, Ulli. (2009). Inspirasi dari Limbah Plastik. Kawan Pustaka. Jakarta

Pravitasari, Anita. (2009). Simbol Daur Ulang pada Botol dan Kemasan Plastik, didownload dari http://majarimagazine.com/2009/02/si mbol-daur-ulang-pada-botol-dankemasan-plastik/

Project B. (2009). Produk Sampah Kemasan, didownload dari http://www.facebook.com/photo.php?pi $\mathrm{d}=100144804 \& \mathrm{op}=1 \& \mathrm{o}=$ global $\&$ view $=\mathrm{g}$ lobal\&subj=1205208724\&id $=12052087$ 24

Putra H.P dan Yuriandala Y, (2010), "Studi Pemanfaatan Sampah Plastik Menjadi Produk dan Jasa Kreatif', Jurnal Sains dan Teknologi Lingkungan, Vol, No.1

Sahwan,F.L dkk, (2005). "Sistem Pengelolaan Limbah Plastik di Indonesia", Jurnal Teknik Lingkungan P3TL-BPPT Vol 6 No.1

Tim Penulis PS. (2008). Penanganan dan Pengolahan Sampah. Penebar Swadaya. Jakarta. 